Biografistyka Pedagogiczna

Rok 2 (2017) nr 1

ISSN 2543-6112; e-ISSN 2543-7399

DOI: 10.36578/BP.2017.02.14

Ryszard Małachowski*

\title{
Kresy Wschodnie II RP kulturowym fundamentem biografii oraz duszpastersko-pedagogicznej i społecznej misji ks. Henryka Nowika (XX-XXI w.)
}

Eastern Borderlands of the Second Polish Republic as the Cultural Foundation of the Biography and the Pastoral, Pedagogical and Social Mission of Fr. Henryk Nowik $(\mathbf{X X}-\mathrm{XXI})$

\begin{abstract}
The article concerns Rev. Dr Henryk Nowik, born in 1933 in the Polish family of religious and patriotic background. He was an acolyte at first, in 1951 admitted to the Seminary in Gorzow Wielkopolski, and in 1957 he was ordained a priest. In 1958 he started studying Philosophy at the Catholic University of Lublin. In 1966 he received a $\mathrm{PhD}$ degree in Philosophy. Serving as a parish priest, he led social and patriotic activity. In the domain of pastoral and educational work: sacerdotal and socio-political, as well as being a chaplain, he took part in social protests of Polish workers, was an adviser to small farmers, inspired the protection of unborn life and organised pastoral pilgrimages of agricultural workers.
\end{abstract}

Rev. Dr Nowik is the "Aristocrat of the Spirit", a morally sensitive man, scholar of asceticism, spirit of prayer and an academic with the extraordinary level of scientific knowledge (theologian, biologist, philosopher, educator). His hidden mystical personality is characterised by not frequently encountered outstanding intellectual and moral culture. He represents decades of great and genuine commitment to his "Homeland", the Catholic Church, the man and the society. Despite the offensive dictatorship of relativism in the twentieth and twenty-first century, he involved in the process of culture

* Ryszard Małachowski-dr, pracownik naukowo-dydaktyczny Uniwersytetu Zielonogórskiego, e-mail: r.malachowski@uz.zgora.pl. 
creation hundreds, if not thousands of Poles dedicated to Homeland and the Church, including academic youth. Therefore, in the opinion of the community of Lower Silesia he is a model priest similar to late Cardinal Stefan Wyszynski, a great personality, confessor and priest-educator. He is a promoter of the historical ethos of "Western Borderlands", a patriot, and a continuator and co-founder of Polish national culture, and at the same he is an eminent social worker, worthy of emulation by lay people and clergy.

Keywords: borderland educational biography, pastoral and educational mission, priest, social worker, patriot

\section{Wstęp}

Istnieją takie państwa i narody, które w ramach przynależnego im terytorium mają specyficzne dla nich „obszary tęsknot”, niezapomniane przestrzenie kulturowe, pewien charakterystyczny typ pogranicza nazywany „Kresami”2. W historiografii polskiej jest to bardzo rozpowszechniona nazwa występująca w dorobku literacko-naukowym, określenie własne ziem Wschodnich I i II Rzeczypospolitej ${ }^{3}$, „naznaczony koniec, cel”", pogranicze tatarsko-wołosko-kozackie (Karol Libelt, 1864), pograniczne strażnice wojskowe ${ }^{5}$, ziemie koronne, tj. południowo-wschodnie I RP ${ }^{6}$. W II RP nazywano je zakordonowymi - jagiellońskimi,

1 T. Chrzanowski, Kresy czyli obszary tęsknot, Kraków 2001.

2 Są to m.in.: Kresy Ostrawskie (Czechy), Siedmiogród (Węgry) (G. Lagazi, Czy Węgrzy mają swoje Kresy Wschodnie?, w: Dziedzictwo Kresów - nasze wspólne dziedzictwo?, red. J. Purchla, Kraków 2006, s. 69) oraz kresy litewskie. W historiografii Litwy kresy oznaczają ziemie ruskie Wielkiego Księstwa Litewskiego i litewskie zajęte przez Polskę: H. Ilgiewicz, Litewska kontestacja pojęcia „Kresy Wschodnie”, w: Europa nieprowincjonalna: przemiany na ziemiach wschodnich dawnej Rzeczypospolitej (Białoruś, Litwa, Łotwa, Ukraina, wschodnie pogranicze III Rzeczypospolitej Polskiej) w latach 1772-1999, red. K. Jasiewicz, Warszawa 1999, s. 124.

3 B. Hadaczek, Historia literatury kresowej, Szczecin 2008, s. 7.

4 T. Chrzanowski, Kresy, s. 5.

5 L. Zasztoft, Kresy 1832-1864, Szkolnictwo na ziemiach litewskich i ruskich dawnej Rzeczypospolitej, Warszawa 1997, s. 21.

6 T. Chrzanowski, Kresy, s. 6. 
zmierzającymi poza granicę wschodnią i północną. Po 1945 r., kiedy w zakres pojęcia „Kresy Wschodnie” weszła Galicja Wschodnia i Lwów, tworzyć się zaczęły współczesne kryteria stosowalności podziału geograficznego na Kresy Północno oraz Południowo Wschodnie ${ }^{7}$. I to Kresy Południowo-Wschodnie okazały się stronami ojczystymi ks. Henryka Nowika.

Kresy Wschodnie Rzeczypospolitej to jeden z najbardziej „pierwotnych” przyrodniczo ${ }^{8}$, zróżnicowanych krajobrazowo ${ }^{9}$, najpiękniejszych regionów Europy $^{10} \mathrm{z}$ ważnymi ośrodkami uniwersyteckimi (Wilno, Lwów). Stanowią symbiozę oryginalnych cech geograficznych, społecznych, politycznych ${ }^{11}$, kulturowych ${ }^{12}$, wyznaniowych, nadających szczególny koegzystencjonalnie charakter wieloetnicznej społeczności kresowej ${ }^{13}$. Dla wielu generacji przed i powojennych Polaków były lub nadal są środowiskiem wychowawczym ${ }^{14}$, utraconym, ale odzwierciedlającym kulturowy fundament życia, niezapomnianą przestrzeń indywidualnych i zbiorowych biografii. Przypisywane Kresom znaczenie formacyjne zapisane jest we wzniosłych, również konfliktogennych i dramatycznych faktach historycznych ${ }^{15}$, pamięci dawnych, odchodzących bezpośrednich świadków i uczestników wielu zdarzeń. Wybitnie patriotyczne jednostki, związane z przełomowymi sytuacjami w dziejach stanowiły poprzez uczestnictwo w nich, integralną część skomplikowanych procesów dotyczących tego obszaru.

7 Encyklopedia Kresów, red. M. Karolczuk-Kędzierska, Kraków [b.r.], s. 9.

8 A. Lewkowska, J. Lewkowski, Zabytkowe cmentarze na Kresach Wschodnich Drugiej Rzeczypospolitej, Województwo wileńskie na obszarze Republiki Białorusi, Warszawa 2007, s. 13.

9 K. Węgorowska, Językowe świadectwa kultury i obyczajowości Kresów Północno-Wschodnich, Utrwalone we wspomnieniach ich byłych mieszkańców, Zielona Góra 2004, s. 458.

10 K. Węglicka, Kresowym szlakiem, „Gawędy o miejscach, ludziach i zdarzeniach”, Warszawa 2006, s. 10.

11 H. Głębocki, Kresy imperium. Szkice i materiały do dziejów polityki Rosji wobec jej peryferii (XVIII-XXI wiek), Kraków 2006, s. 8.

12 Tamże, s. 8.

13 A. Mironowicz, Prawosławni w wielowyznaniowej i wielokulturowej Rzeczypospolitej, w: Chrześcijaństwo $w$ dialogu kultur na ziemiach Rzeczypospolitej. Materiały międzynarodowego kongresu Lublin, 24-26 września 2002 r., red. S. Wilk, Lublin 2003, s. 217.

14 B. Nawroczyński, Polska myśl pedagogiczna. Jej główne linie rozwojowe. Stan wspótczesny i cechy charakterystyczne, Lwów-Warszawa 1938, s. 188.

15 J. Krasowski „Lech”, Wołyński oddział „Kozaka”, Szczecin 1996, s. 3. 
Ich wiekopomny czyn, zachowana wiedza, wspomnienia, składają się na nie ukończoną wielką kresową syntezę historiozoficzną, biograficzną, wychowawczą, której treść zasadniczą stanowi kulturowe dziedzictwo RP.

Gdy w XX w. na świat przyszedł Henryk Nowik, II RP targały niepokojące wydarzenia wewnętrzne ${ }^{16}$ i zewnętrzne. Prowadzone w warunkach różnorodności etnosów, języków, religii i tradycji ${ }^{17}$ destruktywne spory ideologiczne, polemiki dotyczące kwestii ukraińskiej ${ }^{18}$, dyskusje związane z zagrożeniem hitlerowskim i bolszewickim (i socjalistycznym) ${ }^{19}$ zaogniały kryzys. A konflikty graniczne, akcje grabieżcze, sabotażowe, terrorystyczne, zabójstwa dokonywane przez ukraińskich nacjonalistów ${ }^{20}$ na Polakach i Ukraińcach w latach 1930$1932^{21}$, pogłębiały antagonizmy. Ponadto za pomocą międzynarodowych „gier" wywiadowczych, propagandowych, dyplomatycznych i politycznych ${ }^{22}$, wrogie mocarstwa (Związek Socjalistycznych Republik Radzieckich, Niemcy) zmierzały

16 W. Lipiński, Walka zbrojna o niepodległość Polski 1905-1918, Warszawa 1935.

17 Ł. Kapralska, Pluralizm kulturowy i etniczny a odrębność regionalna Kresów południowo-wschodnich w latach 1918-1939, Kraków 2002, s. 96-100.

18 Pacyfikacja Małopolski Wschodniej a geneza Organizacji Ukraińskich Nacjonalistów, w: I. Polit, Miejsce odosobnienia w Berezie Kartuskiej w latach 1934-1939, Torun 2003, S. 10-11.

19 Socjalizm krytycznie oceniał papież Leon XIII (encyklika Rerum Novarum), „bezbożny komunizm" Pius XI (encyklika Divini Redemptoris), marksizm Paweł VI (list Octogesima adveniens) i św. Jan Paweł II (encyklika Centesimus annus); S. Kowalczyk, Z refleksji nad człowiekiem, Człowiek-społeczność-wartość, Lublin 1995, s. 165. Stanowisko socjalistów: Bolesława Limanowskiego, Mieczysława Niedziałkowskiego, Kazimierza Czapińskiego, Ludwika Kulczyckiego wobec bolszewizmu oraz interpretacja liberalna, konserwatywna, piłsudczykowska, komunistyczna i katolicka bolszewizmu w Polsce: m.in. kard. Stefan Wyszyński; M. Kornat, Bolszewizm, totalitaryzm, rewolucja, Rosja, Poczatci sowietologii i studiów nad systemami totalitarnymi w Polsce (1918-1939), cz. 4, Kraków 2003, s. 178-246.

20 Z oddziałów „Zakordot”, tzn. Zakordonnyj Otdieł KP (b)U, Ukraińska Czerwona Powstańcza Organizacja, Ukraińska Rewolucyjna Powstańcza Organizacja, Ukraińska Ludowa Powstańcza Organizacja, w: W. Filar, Wołyń 1939-1944, s. $26,27$.

21 W. Poliszczuk, Dowody zbrodni oun $i$ UPA, Integralny nacjonalizm ukrainski jako odmiana faszyzmu, t. 2: Działalność ukraińskich struktur nacjonalistycznych w latach 1920-1999, Toronto 2000, s. 51-71.

22 Przed 1939 r. „podstawę niemieckiego planu agresji stanowiło dążenie do politycznej i wojskowej izolacji Polski oraz zamiar rozbicia jej siły zbrojnej w ciągu dwu tygodni"; W. Bonusiak, Polska podczas II wojny światowej, Rzeszów 1995, s. 9. 
do istotnego gospodarczo i militarnie ${ }^{23}$ osłabienia państwa polskiego z powodu negatywnego historycznego „praobrazu” ${ }^{24}$ wzajemnych relacji, odmiennych wizji geopolitycznych i strategicznych dotyczących Polski, jej Kresów, i Europy. W tej sytuacji 1 września 1939 r. Niemcy hitlerowskie napadły na Polskę, wybuchła druga wojna światowa, rozpoczęła się ludobójcza okupacja niemiecka oraz radziecka. Jak wynika z powyższego, także z podstawy źródłowej artykułu, dzieje i młodość ks. Nowika miały dramatyczną kresową: historyczną, historiozoficzną i biograficzno-pedagogiczną genezęę i znaczenie. Ze względu na niezwykle złożony kontekst martyrologiczny, a przy tym aksjologiczny walor kresowości, geneza ta stanowi kulturowy fundament biografii oraz duszpastersko-wychowawczej i społecznej misji tejże postaci, również w niniejszym opracowaniu.

\section{Znaczenie wychowawcze kresowych środowisk i przestrzeni kulturowych w biografii ks. Henryka Nowika}

Henryk Nowik ${ }^{26}$ urodził się w ziemi wołyńskiej, w dniu 23 grudnia 1933 r., w osadzie Dębowa Karczma, około 30 kilometrów od Łucka. Przyszedł na świat w domu rodzinnym ${ }^{27}$ Marii (z domu: Ukraińskiej) i Kazimierza Nowika. Województwo

23 E. Kaszuba, System propagandy państwowej obozu rządzącego w Polsce $w$ latach 1926-1939, Toruń 2004, s. 6-7.

$24 \mathrm{~W}$ przedmiocie historiozoficznych oraz historyczno-wychowawczych rozważań stosuje się metaforę. Z konkluzji Tomasza Stryjka powołującego się na Jerzego Topolskiego wynika, iż: „za pomocą metafory historyk konceptualizuje, perswaduje i wizualizuje wyodrębnione przez siebie elementy przeszłej rzeczywistości, istotą zaś owej konceptualizacji jest porównanie. Metafory to obrazowy przekaz złożonych treści, skróty myślowe, pełniące funkcje poznawcze i „unieśmiertelniające” czyny narodu; T. Stryjek, Jakiej przeszłości potrzebuje przyszłość? Interpretacje dziejów narodowych w historiografii i debacie publicznej na Ukrainie 1991-2004, Warszawa 2007, s. 226-227.

25 Materiał źródłowy niniejszego artykułu stanowi publikacja J. M. Grabińskiej, Myśl patriotyczna księdza profesora doktora Henryka Nowika - charyzmatycznego Kapłana oddanego Kościołowi i Ojczyźnie, „Nad Odrą”, (2013) nr 9-12.

26 W artykule wykorzystano wspomnienia Henryka Nowika, Autobiograficzne wspomnienia rodzinne księdza Henryka Nowika, Kresy Południowo-Wschodnie (19182016), Zielona Góra 2016, mps w zbiorach autora publikacji, s. 1-2.

27 Z perspektywy dziecka narodzonego we współczesności (XX/XXI w.) Włodzimierz Fijałkowski stwierdził, iż „miejscem, w którym następuje pierwsze zetknięcie się ze światem poza łonem matki, rzadko bywa dom rodzinny", za: W. Fijałkowski, Urodzić się w domu, w: Oblicza dzieciństwa, red. D. Kornas-Biela, Lublin 2001, s. 335. 
wołyńskie było wówczas drugą pod względem wielkości jednostką administracyjną, istotnie zróżnicowaną narodowościowo ${ }^{28}$. Rodzinna wieś, ulokowana w perspektywie wspominanych przez ks. Nowika kresowych pejzaży, między Boremlem a osadą „Sienkiewiczówką”, brała nazwę od nazwiska wielkiego pisarza szlacheckiego pochodzenia Henryka Sienkiewicza. Z opracowania Apoloniusza Zawilskiego wynika, iż familia Nowików miała także rodowód szlachecki ${ }^{29}$, a rodzice, rodzeństwo i krewni, zamieszkując w wielopokoleniowym, imponującym wielkością oraz zasobnością domu babci, Agaty Ukraińskiej (z domu Czajkowskiej), byli przywiązani do tradycji i zwyczajów tego stanu. W celu ochrony przed podtopieniami, zaspami śnieżnymi, ten typowy dworek położony był przezornie na niewielkim wzniesieniu, częściowo na terenie łączącym osadę Dębową Karczmę z kolonią Piaski ${ }^{30}$. Zmierzając w przeciwnym kierunku, można było dojść do karczmy, którą prowadził miejscowy Żyd. W centralnym miejscu osady bogobojni mieszkańcy ufundowali i postawili chrześcijański krzyż jako votum dziękczynne za ocalenie przed „cholerą". Nowikowie odprawiali przy nim nabożeństwa majowe na cześć Najświętszej Bożej Rodzicielki, Matki Bożej Zielnej, we wspomnieniach księdza pachnące kadzidłami i ziołami polnymi.

Kresowy dom, w którym Henryk zażywał dzieciństwa, wraz z zespołem użytkowych zabudowań: stodołą, oborą, spichlerzem, otoczonych drewnianym, ale solidnym, trwałym płotem, tonął wśród sadów owocowych „ubranych” wiosną w różnorodne kwiecie, latem w soczyste „frukta”, wszelkie rodzaje jesiennych ziół i dojrzałe roje pszczele. Od strony pola rósł „rządowy”, tzn. państwowy, oraz będący własnością Nowików sad śliwkowy, jabłkowy i czereśniowy, przechodzący w aleję skierowaną ku pękatej, imponującej wielkością stodole. Oprócz zebranych snopów stały w niej wiklinowe miotły, drewniane jeszcze grabie, metalowe i drewniane wiadra, rydle tj. wąskie zakończone na okrągło lub ostro łopaty. Być może Henryk lubił przytulać się do jej gorących od letnich promieni, poczerniałych i suchych jak pieprz desek, wdychać woń aromatycznego siana zmieszanego z zapachem pobliskich drzew. Przy stodole znajdował się bowiem

28 Ukraińcy stanowili 68\% populacji Wołynia, Polacy 16,6\%, Żydzi 9,85\%, Niemcy 2,25\%, reszta to Czesi i inne narodowości 2,17\%; W. Filar, Wołyń 1939-1944, s. 26.

29 Samotnia Wicia Ukraińskiego, w: A. Zawilski, Znów ożywają kurhany, Wrocław 1997, s. 65 .

30 Tamże, s. 65. 
sporej wielkości gaj brzozowy, zasadzony przez wuja Michała Ukraińskiego (syna Agaty Ukraińskiej). Dom z okiennicami, chociaż drewniany, najbardziej okazały wśród innych posesji, imponował zabudową. Wzniesiony na kamiennej podmurówce, od przodu z gankiem przyozdobionym artystycznymi metalowymi okuciami, z zimnymi piwnicami (w których składowano warzywa, ziemniaki, wyroby mleczne ${ }^{31}$ ), obszernym strychem (tam magazynowano wędzone wyroby mięsne ${ }^{32}$ ), przykryty był olbrzymim dachem. Od podwórza także przyozdobiono go estetycznym, funkcjonalnym ganeczkiem, prowadzącym do obszernej sieni pełnej podręcznych ubrań, czapek „z usznikami”, „walonek” z filcu - wojłoku tzn. obuwia zimowego, łapci czyli kapci, niezbędnych narzędzi. Sień rozpoczynała się długim korytarzem, w którym stały ciężkie, funkcjonalne szafy, wypełnione kuchennymi garnkami, naczyniami stołowymi i sztućcami. Służyły one do gotowania i serwowania posiłków dla żniwiarzy, „najemników” obsługujących młocarnię, pracujących przy zbiorach w sadach, ogrodzie, dźwigających zboże do wielkiego magazynu podzielonego na „zasieki” na różnego rodzaju ziarna. Tu przechowywano odzież roboczą i pościel dla domowników, sezonowych pomocników, przybywających nierzadko „z dalekich stron”.

Wielopokoleniowa rodzina Nowików, kultywując obyczaje szlachecko-włościańskie (tytuły szlacheckie w II RP zniesiono w 1921 r.), formowała przede wszystkim postawy katolickie i patriotyczne. Dom był miejscem pracy i modlitwy (mały kościół domowy), umiłowania ziemi, nauki i wiary. Szacunkiem otaczano w nim „mądrość dziejową i sędziwe reprezentacje pokoleniowe”, seniorów rodu. Mąż babci (Agaty Ukraińskiej), Mikołaj Ukraiński (dziadek Henryka), w sprawach pedagogicznych raczej łagodnego usposobienia, niepolemiczny, przejawiał wyraźny talent wychowawczy (rodzone córki go uwielbiały). Natomiast wspomniany syn, Michał Ukraiński ${ }^{33}$ i jego energiczna matka okazali się prawdziwymi gospodarzami. Pod okiennicami domu, także w przydomowym ogrodzie, z pomocą rodziców Henryka i rodzeństwa sadzili podziwiane przez sąsiadów, ozdobne, starannie pielęgnowane: malwy, róże, piwonie, storczyki, floksy i lilie. Ojciec pracował dodatkowo w przynależnym do rodziny młynie.

31 H. Nowik, Autobiograficzne wspomnienia rodzinne, s. 2.

32 Tamże, s. 2.

33 Całością gospodarstwa zarządzał Michał Ukraiński (wuj ks. Nowika); J. M. Grabińska, Myśl patriotyczna księdza profesora, s. 11. 
Obrzeża zabudowań „ubierał” i strzegł „groźny”, krzaczasty, zielony agrest, zdobiły czerwone porzeczki, przy wspomnianej drodze wznosił się wysokopienny biały bez. Być może wzorem innych gospodarzy sadzono tu maliny ${ }^{34}$ do celów ozdobnych bądź użytkowych, spożywane na Kresach z cukrem pudrem. Przed jednopiętrową posesją, z zawsze dymiącym kominem, stała ława do wieczornych, sąsiedzkich spotkań i oparty o frontową ścianę pierwszy we wsi rower, jeszcze bez przerzutek. Wewnątrz na końcu korytarza znajdowało się pomieszczenie łazienne z paleniskiem ogrzewającym zbiornik wody, balią (małą wanną do kąpieli), z blaszaną i falistą „tarką" spełniającą rolę ówczesnej pralki.

Po prawej stronie dostrzegało się obszerną izbę kuchenną, piec nakryty „ślepymi" płytami pozbawionymi otworów, z dającymi sporo ciepła fajerkami. Dla wygody przytwierdzono nad nim pogrzebacz (haczyk) do rozdrabniania węgla, żaru, wybierania popiołu, długą półkę z listwą chroniącą od strącenia i potłuczenia talerze, miski, półmiski, makutrę (do ucierania maku drewnianą, zaokrągloną kopyścią), patelnie, drewniane łyżki do mieszania gotowanych posiłków (najczęściej zup, ziemniaków, bigosu). Nieopodal stała „centryfuga” do oddzielania śmietany od surowego mleka. W czasie przedwigilijnym nad piecem suszono znalezione w lesie grzyby, a zebrane w sadzie śliwki i jabłka przeznaczano na tradycyjny wigilijny kompot. Bowiem w kresowym środowisku ziemiańskim święta Bożego Narodzenia ze świętami Wielkiej Nocy i Zielonych Świąt były uważane za najważniejsze ${ }^{35}$.

Pod piecem kuchennym tkwiło duże palenisko, niżej pod nim wygospodarowano funkcjonalną przestrzeń do przesychania żywicznego drewna. Zgromadzone w większym koszu polana, drzazgi i szczapy wykorzystywano w porach chłodu, jesiennego deszczu, szczególnie „zimową porą" do ogrzewania pomieszczeń mieszkalnych. Izbę kuchenną zdobił solidny, dębowy kredens z lustrem w środku, zastawą stołową i dużym pudełkiem zapałek. Przy ścianie stała solidna, obszerna ława. Rodzina siadała jednak przy dużym prostokątnym stole z blatem dębowym, otoczonym krzesłami stylizowanymi na ludowo. Łączył on domowników w czasie posiłków, rozmów, modlitw ustnych i śpiewanych, czynionych planów, wspomnień smutnych i wesołych wieści. Wieczo-

34 W. Filar, Wołyń 1939-1944, s. 26.

35 T. A. Pruszak, O ziemiańskim świętowaniu. Tradycje świąt Bożego Narodzenia i Wielkiejnocy, Warszawa 2011, s. 11. 
rem na stole stała lampa naftowa, a nad nim wisiał krzyż. Zajmując miejsce na krześle można było patrzeć na pole, kontemplując zachód słońca przez okno przybrane białymi firankami, kolorowymi zasłonami z kwiecistymi wzorami. Gospodyni przyozdabiała również parapety stawiając w kamionkowych doniczkach modne wówczas pelargonie na ceramicznych podstawkach.

Na prawo od korytarza znajdowały się dwa obszerne pokoje i trzeci mniejszy z kaflowymi piecami i biblioteką. Wchodziło się tam do czterech pomieszczeń mieszkalnych, jednego mniejszego przeznaczonego dla okolicznościowego gościa. I tutaj duży krzyż na ścianie, przybrany kwiatami mały ołtarzyk, biało-czerwone godło II RP czyli Orzeł w koronie, fotografia marszałka Józefa Piłsudskiego, portrety rodowe i inne powiększone zdjęcia, świadczyły o polskości kresowego domu. Nabyty w czasie drugiej wojny światowej przez mamę Henryka duży obraz Matki Bożej Niepokalanie Poczętej z Niepokalanowa, podobnej wielkości przekazywane z pokolenia na pokolenie przez seniorów rodu cztery inne (Serce Matki Bożej, Najświętsze Serce Pana Jezusa, św. Teresy od Dzieciątka Jezus, prastary obraz rodowy Anioła Stróża chroniącego dziecko nad przepaścią), podkreślały religijność i patriotyzm środowiska rodzinnego. Wysoki, zaradny, opiekuńczy i silny fizycznie ociec dbał o gospodarstwo i rodzinę. Praktyczny, otwarty na nowinki techniczne, sprowadził do domu aparat fotograficzny, kupił zapobiegliwej, troskliwej żonie kołowrotek do przędzenia wełny i wyrobu nici. Nabył żeliwną w kolorze czarnym „terkoczącą" maszynę do renowacji podniszczonych ubrań. Za sprawą mamy powstawały także robione na drutach skarpety, swetry, czapki, rękawiczki, szale jako prezenty pod choinkę, na szydełkach ozdobne koronki do pościeli oraz serwetki przeznaczone na stół pod szklane i kryształowe wazony oraz flakony. Wśród zimowej zawiei, śnieżnej ciszy i mrozu, poruszający wahadłem zegar na ścianie tykał jednostajnie, nostalgicznie wyznaczając godziny dnia. W narożniku pokoju domownicy w skupieniu czytali gazetkę „Rycerz Niepokalanej”, wydawaną cyklicznie przez ojca Maksymiliana Marię Kolbego w dalekim Niepokalanowie. Przy innych okazjach włączany patefon odtwarzał rytmiczne dźwięki popularnych przedwojennych utworów ${ }^{36}$.

36 Ta ostatnia niedziela, Pieśn o Matce (Mieczysław Fogg), Miłość ci wszystko wybaczy, Mein Judische mame (Hanka Ordonówna), Już taki jestem zimny drań (Eugeniusz Bodo), A mnie jest szkoda lata (Andrzej Bogucki), Piosenka o mojej Warszawie (Albert Haris), Tylko we Lwowie (Szczepko i Tońko). 
Najczęściej, bo codziennie, pojedynczo lub wspólnie modlono się na Kresach pieśniami religijnymi i patriotycznymi, do których zachęcała mama: Kiedy ranne wstaja zorze, Gorzkie żale przybywajcie, Boże coś Polskę, Bogurodzica, Rota, My I Brygada, Marsz Polonia, Panience na dobranoc, Cisza. Zwyczaj wspólnotowego śpiewania „Mamusia zaprowadziła w swoim domu z sąsiadami nie tylko w czasie Wielkiego Postu"37.

Pieśniom patriotycznym „obowiązkowo" towarzyszył akompaniament ojca grającego na modnej i popularnej harmonii (akordeon). Wujek Wicio choć był samotnikiem rozczytanym „w swych" książkach ${ }^{38}$, przy tej okazji towarzyszył mu na mandolinie. Brat Henryka, Wacław, z zaangażowaniem akompaniował na zmianę z ojcem na akordeonie. Także pracom domowym, w których dzieci brały udział, towarzyszył śpiew mamy. Była to osoba wyjątkowa. Dbając o wszystkich, wytrwale budowała autorytet Boga, Kościoła i Ojczyzny, rodziny, rodziców, dziadków. Scalając bliskich, starała się osiągać chrześcijańską doskonałość w pełnionych obowiązkach. Rodzeństwo bardzo lubiło wspólne posiłki z tatą i mamą, podającą na śniadanie wyrabiane własnym sumptem: zupy, np. kluski lane na mleku (kto chciał, korzystał z cukru), chleb z masłem, jajecznicę, wędlinę, kawę z mlekiem (Henryk nie słodził). Na obiad spożywano: barszcz ukraiński zaprawiany śmietaną i octem jabłkowym, zupę z zebranego przez dzieci na łąkach szczawiu, rosół z najtłuściejszej kury lub gęsi, bigos z grzybami i kiełbasą. Henryk cieszył się szczególnie, gdy mama przygotowywała „pampuszki” pieczone w brytfankach z tartych ziemniaków, z dodatkiem mąki i dużych plastrów boczku z cebulką. Ze smakiem spożywano pierogi ruskie (z farszem ziemniaczanym, białym serem i pieprzem), kaszę gryczaną, ziemniaki z mięsem i maślanką. Czas „ciepłej” kolacji zapowiadał aromat: żuru z białą kiełbasą i kostkami suchego chleba, krupniku ze świeżym chlebem, bułki prażonej na mleku w brytfance, kawy zbożowej z mlekiem, chleba z powidłami śliwkowymi, truskawkowymi lub kawałek ciasta drożdżowego. Wszystko to było integrująco i atrakcyjnie połączone z kresowymi gawędami rodziców, dziadków, krewnych, gości, tworząc pogodne dopełnienie przedwieczornej ciszy oraz często gwiaździstej i księżycowej nocy.

37 H. Nowik, Autobiograficzne wspomnienia rodzinne, s. 1.

38 Samotnia Wicia Ukraińskiego, s. 65-65. 


\section{Grupa rówieśnicza jako kresowa wieloetniczna społeczność wychowawcza ks. Nowika}

Kolejny dzień wieloetnicznej osady wczesnym, jeszcze chłodnym, kresowym świtem zaczynał się modlitwą. Nie bez różnic i sporów ${ }^{39}$ sąsiedzkie, gospodarskie i kulturalne relacje Polaków, Ukraińców i Czechów układały się na ogół poprawnie. Wieczorne zabawy, tańce, śpiewanie rzewnych dumek ukraińskich, miejsce urodzenia, pochodzenia społecznego i wyznanie, szacunek do innych narodowości stanowiły czynniki łączące ludzi. W osadzie dobrze prosperował rosły kowal i akustyczna kuźnia wydająca metaliczne dźwięki, uzdolniony stolarz „artysta” podziwiał zapisane przez siebie w drewnie bogate ornamenty, znachorka monotonnie zaklinała złe duchy i choroby. Na drodze cierpliwie turkotał popularny „drabiniak” (drewniany wóz do przewożenia snopów), który w ramach pomocy sąsiedzkiej mógł zabrać z obawy przed „ulewą" czyjeś zboże. Polski inteligent chętnie pisał Ukraińcowi podania do urzędów, zyskując wdzięczność i szacunek. W miejscowym środowisku polskie, ukraińskie, żydowskie, czeskie dzieci i młodzież tworzyły dobrze funkcjonujące grupy rówieśnicze: koleżeńskie, szkolne, harcerskie, teatralne, sportowe. Ks. Nowik wspominał:

[...] w sezonie wiosennym, letnim $\mathrm{i}$ jesiennym przebywaliśmy na dworze. Graliśmy w piłkę ręczną i nożną z dziećmi z sąsiednich zagród, organizowaliśmy „wyścigi” na jedynym we wsi rowerze, bawiliśmy się w czasie nadzorowanych przez dorosłych zabaw, wykonując proste do tego zabawki. Sroga i wietrzna zima także zapowiadała wielką radość. Gdy już nocą lub od rana padał śnieg, lepiliśmy bałwana, nad głowami wirowały śnieżki, zjeżdżaliśmy na sankach, ścigaliśmy się na „domowej roboty" drewnianych łyżwach

39 Zdaniem Łucji Kapralskiej w warunkach pogranicza Kresów Południowo-Wschodnich proces asymilacji polskiej i ruskiej grupy etnicznej, mimo otwartości pierwszej grupy charakteryzującej się brakiem przymusu asymilacyjnego, ale jak sądzę wyższym stopniem odczuwanej ekskluzywności, nie nastąpił. Kształtowanie tożsamości ruskiej grupy etnicznej, jej przebudzenie narodowe, wytworzenie podziału „swójobcy", konflikty etniczne, przy rutenizacji części społeczności polskiej, wstrzymały proces asymilacyjny, przyspieszając „uformowanie się na Kresach Południowo-Wschodnich odrębnego narodu ukraińskiego"; Ł. Kapralska, Pluralizm kulturowy $i$ etniczny, s. 143-144. Wspomniany ekskluzywizm polonocentryczny wyrażał się choćby w używaniu języka polskiego (większościowego i urzędowego), rozumieniu go przez około 80\% populacji Kresów Południowo-Wschodnich; tamże, s. 213. 
przywiązanych drutem do butów. Był to stały styl zabaw, które nie wiadomo kiedy, wraz z wiekiem wygasły. Przychodził czas odpowiedzialnej troski o dom, szkolne zajęcia, bardziej zaangażowanej duchowo i wspólnotowo modlitwy, nastrojowej jesiennej i zimowej zadumy. Chętnie przebywaliśmy w kuchni przysłuchując się z ciekawością pogodnym, ale też poważnym tematom rodzicielskich rozmów. Dojrzewaliśmy do życia i obowiązków ${ }^{40}$.

Nadal aktualnym zadaniem wychowawczym „w niespokojnej Europie i Kresach" było wpajanie miłości i obrony Ojczyzny. Uczyły tego polskie rodziny, w tym rodzina Nowików, tworzące w społeczeństwie wieloetnicznym atmosferę religijno-patriotycznej przestrzeni szlacheckiego domu, w którym szanowało się Boga, Kościół, Ojczyznę i „ojcowiznę”. Każdy dwór polski na Kresach był miejscem pamięci historycznej ${ }^{41}$, a rodzice, księża i nauczyciele stanowili z wychowankami zintegrowane wychowawczo wspólnoty, realizujące zweryfikowane kulturowo, historycznie i temporalnie obyczaje. Na podstawie transmisji wiary przodków, patriotyzmu opartego na tradycjach powstańczych - listopadowych (1830) i styczniowych (1863) - wzorze Marszałka Józefa Piłsudskiego chronionym osobną ustawą sejmową, istotnym formacyjnie środkiem wychowawczym był szacunek do pamięci przeszłości i „przyszłości”. Wdrażano do poszanowania wytrwałej modlitwy, troski o rodzinę i najbliższych, rozwijania kultury rolnej, propagowania kultury umysłowej, religijnej, fizycznej. Rodzice zapewniali dzieciom i młodzieży rozwój intelektualny przez: czytanie (dzieł: Marii Dąbrowskiej, Kornela Makuszyńskiego, Janusza Korczaka, Gustawa Morcinka, Ewy Szelburg-Zarembiny, Janiny Porazińskiej ${ }^{42}$ ), szeroko rozumianą edukację, naukę języków obcych, historii Polski, polskiej literatury ${ }^{43}$, muzyki, tradycji i oby-

40 H. Nowik, Autobiograficzne wspomnienia rodzinne, s. 2.

41 B. Sokołowska, Romantyczne znaki ocalenia w epopei na Wysokiej Połoninie Stanisława Vincenza, w: O dialogu kultur wspólnot kresowych, red. S. Uliasz, Rzeszów 1998, S. 109.

42 J.Z. Białek, Literatura dla dzieci i młodzieży w latach 1918-1939. Zarys monograficzny, Materiaty, Warszawa 1979, s. 218-298.

43 Dzieła m.in.: Marii Buyno-Arctowej, Juliusza Kaden-Bandrowskiego, Zofii Żurakowskiej; J.Z. Białek, Literatura dla dzieci i młodzieży, s. 301-346. Zapewne nieobce dzieciom i młodzieży były utwory: Ignacego Krasickiego Hymn do miłości Ojczyzny, Adama Kazimierza Czartoryskiego Katechizm moralny dla uczniów Korpusu Kadetów, Kazimierza Brodzińskiego Żal za językiem polskim; I. Kaniowska-Lewańska, 
czajów. Dbano o jakość i zasobność domowej biblioteki, wspomnianą kulturę czytelniczą, jako jedne z najistotniejszych wartości wychowawczych ${ }^{44}$ okresu międzywojennego (1918-1939). Przewodziła temu wspomniana babcia Agata Ukraińska, skłaniająca domowników i wnuki do częstej lektury m.in. dzieł Józefa Teodora Konrada herbu Nałęcz (Jospeh Conrad ${ }^{45}$ ), Pana Tadeusza Adama Mickiewicza, którego Henryk czytał potem przez całe życie. Znaczenie książki wspominał w późniejszych latach następująco:

Biblioteka była duża jak na owe czasy. Nie wiedziałem o czym mówią te książki. Ich tajemnica mnie pociągała. Siostra Danuta od czasu do czasu czytała na głos, chętnie ją słuchałem [...]. Książka stawała się jakoś bliższa [...]. Chętnie słuchałem „Pana Tadeusza”. Była tam mowa o Matce Bożej z Ostrej Bramy, a ja z mojej ściany znałem Matkę Bożą Niepokalaną, która mnie wybawiła ze śmiertelnej choroby ${ }^{46}$.

Mając tak wymagający wzorzec kulturowo-wychowawczy, w życiu dorosłym dysponował imponującym zasobem woluminów "narodowych” oraz naukowych.

Dzięki wrodzonym dyspozycjom i „książkom” chłopiec ten od lat dziecięcych wyróżniał się zdolnościami intelektualnymi (matematycznymi i humanistycznymi), oczytaniem, spostrzegawczością, mającymi znaczenie w jego późniejszej działalności. Przywiązany do rodziców i rodzeństwa o sobie mówił niewiele. Znamionowała go niepospolita wrażliwość, dyskrecja, pogoda ducha, zdrowy humor, uczuciowość, szczególne miłosierdzie wobec ubogich oraz wielkie poczucie sprawiedliwości i wdzięczności. Otaczana szacunkiem i podziwem mama, nie wyróżniając nikogo, kochała wszystkich. Wyczuwając osobliwość natury syna, być może widziała w nim przyszłego kapłana, gdyż nader często wskazywała mu najwyższe wartości do realizacji i autorytety. W pewnej chwili życia w pamięci przyszłego księdza utrwalił się obraz ciężko pracującej rodzicielki obejmującej

Literatura dla dzieci i młodzieży do roku 1864, Zarys rozwoju, Wybór materiałów, wyd. 2 zmienione i poszerzone, Warszawa 1973, s. 207-211.

44 "Literatura dla dzieci i młodzieży i pedagogika spełniają podobne funkcje wychowawcze i zmierzają do wspólnych celów"; B. Hadaczek, Wychowanie przez literaturę w Polsce międzywojennej (zwiazki literatury dla dzieci i młodzieży z pedagogika), Rozprawy i Studia, t. 4, Warszawa-Poznań, s. 3.

45 Samotnia Wicia Ukraińskiego, s. 70.

46 H. Nowik, Autobiograficzne wspomnienia rodzinne, s. 2. 
łany pszenicy, mówiącej: „patrzcie dzieci to jest moje złoto, to jest mój skarb”"47. Takie wyznanie potwierdza właściwą u niej hierarchię dóbr. Bowiem po Panu Bogu i Matce Bożej największą miłością darzyła męża i potomstwo, dla których pracowała. W przekonaniu religijnych rodziców to właśnie Henryk, brat jego Wacław i siostra Danuta cudem zostali „wróceni do życia”, ze śmiertelnej w okresie międzywojennym szkarlatyny, za wstawiennictwem Najświętszej Marii Panny ${ }^{48}$. Od tej chwili oprócz wytrwałej modlitwy do „Pani Jasnogórskiej - Królowej Polski", jak zawsze wspominał, równie szczególnie modlili się z całą rodziną, oddając cześć „przyczynie” uzdrowienia - Maryi Niepokalanie Poczętej.

\section{Druga wojna światowa i czas powojenny dojrzewaniem Henryka Nowika do stanu kapłańskiego}

Gdy dnia 1 września 1939 r. II RP została zaatakowana, niemal sielskie dotąd dzieciństwo sześcioletniego Henryka nagle się skończyło ${ }^{49}$ : „Z domu wyprowadził nas złowrogi czas. Byliśmy dziećmi wojny"50. Z kupionego przez ojca w $1938 \mathrm{r}$. radioodbiornika dowiedziano się si $^{1}$ iż w 1939 r. Związek Sowiecki dokonał bezprawnej w świetle prawa międzynarodowego inwazji. Już po dwóch tygodniach walk front zbliżał się niebezpiecznie szybko do Wołynia. W czasie działań militarnych wrogo nastawiona do religii Armia Czerwona niszczyła miejsca kultu (kościoły i inne świątynie), bombardowała miasta i szkoły, paliła wsie, osady, chutory, przysiółki, kolonie i „gniazda”. Dokonywała fizycznej eliminacji szczególnie polskiej ludności cywilnej, masowej eksterminacji księży katolickich i duchownych innych wyznań. Na odcinku wołyńskim zadania obronne pełniły początkowo tylko dwa pułki Korpusu Ochrony Pogranicza: Sarny ${ }^{52}$ i Równe.

47 J. M. Grabińska, Myśl patriotyczna księdza profesora, s. 11.

48 Tamże, s. 11.

49 Z. Okoń, Kresowi sąsiedzi. W szponach trzech ludobójczych hord, Rzeszów 2005, s. 38.

50 H. Nowik, Autobiograficzne wspomnienia rodzinne, s. 2.

51 Ze względu na słabość rodzimego kapitału medialnego w dwudziestoleciu międzywojennym podstawowym środkiem komunikacji społecznej była w większości prasa, E. Kaszuba, System propagandy państwowej, s. 91.

52 Informacje o stacjonowaniu na Wołyniu pułku piechoty KоР „Sarny” oraz pp KOP „Zdołbunów” potwierdza Czesław Piotrowski, Wojskowe i historyczne tradycje 27. Wotyńskiej dywizji Piechoty Armii Krajowej, Warszawa 1993, s. 35. 
Wkrótce, 18 września gen. bryg. Mieczysław Makary Smorawiński wobec przeważających sił wroga ogłosił demobilizację, a po zajęciu przez Armię Czerwoną Włodzimierza, 19 września 1939 r., podpisał akt kapitulacji1 ${ }^{53}$.

W grudniu tego samego roku, po podziale Wołynia na obwód wołyński i rówieński, sytuacja ludności polskiej się pogarszała. Rosyjscy okupanci podsycali propagandę antypolską, podjudzając Ukraińców generujących konflikty i zbrodnie narodowościowe. W wyniku działań wojennych, strat osobowych, wielu pomordowanych, przemieszczania się uchodźców, brania jeńców, wywózek Polaków, przesiedlania ludności niemieckiej do III Rzeszy nastąpiła zmiana liczby ludności Kresów Wschodnich, w tym Wołynia, i jej struktury społeczne ${ }^{54}$. Sytuację komplikowała rutenizacja, wymuszanie deklaracji lojalności wobec nowych władz, przymusowe nadawanie obywatelstwa rosyjskiego. Wywłaszczano właścicieli majątków ziemskich, tworzono sowchozy, nacjonalizowano przedsiębiorstwa przemysłowe i banki, grabiono wszystko, co można było wywieźć w głąb Związku Sowieckiego. Zrusyfikowano szkolnictwo, system nauczania, wychowania, programy szkolne, zabijano nauczycieli, duchowieństwo katolickie, greckokatolickie i prawosławne. Zagrożone było również życie Henryka, rodziców i rodziny. Za pierwszym razem ocalenie zawdzięczali szlachetnej sąsiadce, sędziwej Ukraince, która klęcząc na kolanach przed ukraińskimi oprawcami, „ofiarowała” za Nowików swoje życie ${ }^{55}$. Na szczęście dla jednych i drugich egzekucja nie nastąpiła, a rodzina zbiegła do Łucka.

53 W. Filar, Wołyń 1939-1944, s. 39, 41. Po wkroczeniu Armii Radzieckiej część zdezorientowanych sytuacją oddziałów podjęła walkę, część się poddała; C. Piotrowski, Wojskowe i historyczne tradycje, s. 20.

54 Przesiedlenie ludności polskiej z Kresów Wschodnich do Polski 1944-1947, wyb., oprac. i red. S. Ciesielski, Warszawa 1999, s. 10-12; G. Hryciuk, Zmiany ludnościowe i narodowościowe w Galicji Wschodniej i na Wołyniu w latach 1939-1948, w: Przemiany narodowościowe na Kresach Wschodnich II Rzeczypospolitej 1931-1948, red. S. Ciesielski, Torun 2003, s. 165-167. Straty zadane ludności polskiej w latach 1939-1945: W. Siemaszko, E. Siemaszko, Ludobójstwo dokonane przez nacjonalistów ukraińskich na ludności polskiej Wołynia 1939-1945, t. 2, s. 1033; 1056; m.in. poznańska artystka malarka Zofia Małachowska-Gerżbakowa (zm. w 1942 r. w Krakowie), profesor chemii organicznej we Lwowie Roman Małachowski (zginął w 1944 r. w Powstaniu Warszawskim), dziennikarz Czesław Zienkiewicz („zmarł”); Lista strat kultury polskiej (1.IX.1939 - 1.III.1946), zestawił B. Olszewicz, Warszawa 1947, s. 1-327.

55 W. Siemaszko, E. Siemaszko, Ludobójstwo, t. 2, s. 1063. 
Zamieszkawszy na osiedlu „Krasnym”, potem w pobliżu katedry pw. świętych Piotra i Pawła przy ul. św. Jadwigi, Henryk mógł obserwować posługujących tu kapłanów, ucząc się szacunku do nich. Tutaj został ministrantem, mając niewzruszone przekonanie o otrzymaniu proroctwa, dotyczącego powołania go przez Boga do stanu kapłańskiego. Bowiem
pewnego razu, po nieszporach, gdy już światła były częściowo [w katedrze] wygaszone, mając niespełna dziesięć lat modlił się przed obrazem Matki Bożej Latyczowskiej - przy głównym ołtarzu, nagle poczuł, że ktoś dotknął jego ramienia a następnie usłyszał głos „Będziesz księdzem”. [... [ ten dotyk cały czas czuł przez lata ${ }^{56}$.

Młody wiek oraz dramatyczne okoliczności kazały powyższe zdarzenie i związane z nim decyzje na razie oddalić.

Po wielu perypetiach, które można by nazwać za Krystyną Kersten: „historią ludzi na drogach" ${ }^{\prime 57}$ wojny, w 1943 r. rodzina zatrzymała się w Otwocku. Pan Nowik został zatrudniony we młynie, a przychówek (Danuta, Henryk, Wacław $^{58}$, Teresa, Jan) powiększył się o szóste dziecko, o córeczkę Zosię. Ponadto (w 1943 r.) Wołyń stał się zapleczem frontu niemieckiego, miejscem koncentracji wojsk, jednostek logistycznych, ewakuacji pracowników administracji ${ }^{59}$. Przybywszy do stolicy, samotna matka (ojciec z niewiadomych powodów nie dotarł z Łucka) z dziećmi na krótko zamieszkała u brata męża przy ul. Freta 42. Po czym już 2 grudnia 1943 r. wszyscy w pośpiechu i niepewności udali się bez dokumentów osobistych do Kowla, następnie znowu do Łucka. Od tragicznych skutków nieposiadania dokumentów, w momencie kontroli na stacji w Chełmie, przed ukraińskimi żandarmami uratował ich żołnierz, prawdopodobnie śląskiego pochodzenia. Nie bacząc na tułaczkę, realną możliwość wykolejenia pociągu w eksplozji za sprawą partyzantów radzieckich lub polskich, pośród

56 J.M. Grabińska, Myśl patriotyczna księdza profesora, s. 12.

57 A. Rokuszewska-Pawełek, Chaos i przymus, Trajektorie wojenne Polaków - analiza biograficzna, Łódź 2002, s. 131.

$58 \mathrm{Na}$ początku października $1977 \mathrm{r}$. Wacław zaginął, po czym wydobyto jego ciało z rzeki Warty w miejscowości Uniejów (listopad 1977 r.). Niezniszczone dokumenty mogą wskazywać na nieprzypadkowe utonięcie; J. M. Grabińska, Myśl patriotyczna księdza profesora, s. 14.

59 W. Filar, Wotyń 1939-1944, s. 115. 
kpin z różańca noszonego na szyi, których dopuścił się pewien kolejarz, mama prosiła usilnie maszynistę pociągu zmierzającego $\mathrm{z}$ transportem wojskowym na front wschodni, o możliwość przejazdu dla siebie i dzieci. Po dłuższej chwili niepewności i zapewniania kolejarza o szczęśliwym przebiegu podróży, dzięki modlitwie pani Nowikowej do Matki Bożej na tymże różańcu, pociąg szczęśliwie dojechał do Kiwerzec, a następnie do celu podróży (Łuck).

W czasie wojny ojciec Henryka zginął tragicznie w bliżej nieznanych okolicznościach pod Garwolinem, wioząc części zamienne do silnika młyńskiego na trasie z Lublina do Otwocka. Od tej chwili matka, jedyna żywicielka, żądała od dzieci jeszcze większej rzetelności w nauce, obowiązkowości, pracowitości, odpowiedzialności, zawierzenia się Bogu i Matce Bożej bez reszty. Nadal wskazywała na autorytety moralne w rodzinie: nieżyjącego już, czule pamiętanego męża ${ }^{60}$ Kazimierza, wujków Henryka: Olesia (absolwent Uniwersytetu we Lwowie ${ }^{61}$ ) i Wicia (ukończył gimnazjum klasyczne, następnie Wyższą Szkołę Handlową w Łucku ${ }^{62}$ ), Michała, który zachwycał pięknym charakterem pisma (zajmował się gospodarstwem), rodzoną siostrę matki - Annę (imię zakonne Albina) ${ }^{63}$. Henryk miał autorytetów trochę więcej, m.in. późniejszego ojca duchownego ${ }^{64}$

6o Ojcostwo Boże było źródłem i wzorem ojcostwa ziemskiego taty ks. Nowika; B. Mierzwiński, Ojcostwo Boże źródłem i wzorem ojcostwa ziemskiego, w: Oblicze ojcostwa, red. D. Kornas-Biela, Lublin 2001, s. 27.

61 Po aneksji Kresów Wschodnich II RP dokonano sowietyzacji polskich uczelni wyższych w latach 1939-1941; S. Kalbarczyk, Polscy pracownicy nauki. Ofiary zbrodni sowieckich w latach II wojny światowej. Zamordowani, więzieni, deportowani, Warszawa 2001, s. 11-46. Kolejny etap sowietyzacji realizowano po 1945 r.

62 A. Zawilski, Znów ożywają kurhany, s. 65-70.

63 J. M. Grabińska, Myśl patriotyczna księdza profesora, s. 12. Urodzona w Dębowej Karczmie, w 1892 r., mając lat 22, Anna wstąpiła do klasztoru sióstr albertynek w Zakopanem na Kalatówkach. Pracując w Pustelni brata Alberta, z charakteru pogodna i zdyscyplinowana, w wieku lat 38 przeczuwała śmierć. Jednak w posłuszeństwie przełożonej wypełniła dane jej polecenie wyjazdu na zakupy, w czasie którego zginęła w drodze powrotnej 4 grudnia 1930 r., zmierzając z Kalatówek do Kuźnic [informacja uzyskana od ks. Nowika].

64 Wskazuję na ojcostwo duchowe człowieka jako ojcostwo Boga; A. J. Nowak, Teologia ojcostwa, w: Oblicze ojcostwa, s. 29; ojcowska posługa kapłana wyraża się także szczególnie w regularnym sprawowaniu kierownictwa duchowego, przez które prowadzi on daną osobę na drogach życia duchowego, za: A. Derdziuk, Ojcostwo kapłana, w: Oblicze ojcostwa, s. 160 . 
ks. Bernarda Witucha, który wzbudził w nim kult Miłosierdzia Bożego, siostrę Faustynę Kowalską, ks. dr. Michała Sopoćkę, więźnia łagru w Kazachstanie ks. Karola Gałęzowskiego (1879-1950), apostoła Kazachstanu - błogosławionego ks. Władysława Bukowińskiego (1904-1974) ${ }^{65}$. Ucząc się od nich heroicznego zaufania Bogu, czekał na zakończenie wojny.

W 1945 r. po ustaniu działań wojennych w Polsce i Europie, do rodzinnej Dębowej Karczmy Nowikowie już nigdy nie wrócili. Jednak nie tylko traumatyczne wydarzenia historyczne, niezbędne doświadczenia historiozoficzno-pedagogiczne, ale także specyficznie wychowawcze piękno architektoniczne, przyrodnicze kresowej ziemi, szczególnie wychowanie rodzinne, społeczne i szkolne, utrwalały w miłość do miejsca urodzenia. W pamięci pozostały mu przedwojenne wieloetniczne miasta, miasteczka, wsie, ziemiańskie dwory, dworki i pałace ${ }^{66}$, kina, teatry, sklepy, targi i stragany, urzędy administracji lokalnej. Nostalgiczną specyfikę nadawały kresowym wspomnieniom niezmierzone stepowe, pagórkowate, zalesione przestrzenie, małe jakby uśpione w promieniach słońca, deszczu i mgłach prowincje: osady, szkoły, kościoły chrześcijańskie, żydowskie synagogi, dawne nekropolie, współczesne cmentarze, stacyjki kolejowe, okazalsze stacje, posterunki policji, koszary wojskowe. Radosne ożywienie budziły przemarsze i defilady orkiestr w mundurach żołnierskich, policyjnych, strażackich, organizacji młodzieżowych w tym harcerskich. Wszystko to ze wzruszeniem wspomina dzisiaj, jako świat utracony, świat kresowej tęsknoty i powołania Bożego.

W powojennej Polsce władze komunistyczne starały się wyrugować z pamięci narodu fundamenty kresowej kultury i religii katolickiej, niepodległości państwa i wolności Kościoła rzymskokatolickiego ${ }^{67}$, jednak nie przeszkodziło to Henrykowi zmierzać ku studiom filozoficzno-teologicznym. Będąc absolwentem szkoły podstawowej klas od czwartej do szóstej (ukończonych w Jabłonnej, Świerku, Otwocku), do klasy siódmej poszedł we Lwówku Wielkopolskim w 1948 r., po czym rodzina przeprowadziła się do wsi Chmielinko (woj. poznańskie). W tym czasie mama jego przebywała w Otwocku, a syn pragnął

65 J. M. Grabińska, Myśl patriotyczna księdza profesora, s. 12.

66 B. Hadaczek, Historia literatury kresowej, s. 87.

67 M. Parzyszek, Rodzina w nauczaniu kardynała Stefana Wyszyńskiego. Aspekt pedagogiczny, Lublin: 2012, s. 46-57. 
pomagać jej i rodzeństwu finansowo jak najprędzej, odwdzięczając się za bezgraniczne poświęcenie. Pod koniec 1948 r. zamieszkali wszyscy w jednym domu w tymże Chmielinku, utrzymując się z pracy w niewielkim gospodarstwie rolnym $^{68}$. Wtedy to nadszedł czas, gdy w 1948 r., umocniony prorockim snem ${ }^{69}$, z kolegą Janem Makowskim wstąpił do Niższego Seminarium Duchownego w Słupsku, przy ul. Szymanowskiego 5. Wychowawcą nowych alumnów był ks. Józef Ferensowicz ${ }^{70}$. W 1951 r. po zdaniu egzaminu maturalnego, ale „na prawach kościelnych", Henryk został przyjęty do Wyższego Seminarium Duchownego w Gorzowie Wielkopolskim na Kresach Zachodnich. Studia teologiczne, rozpoczęte w 1956 r. „na kredyt”, z obowiązkiem złożenia jak najszybciej matury państwowej, uzupełnił o wymagane programem nauczania studia filozoficzne w warszawskiej Akademii Teologii Katolickiej (АTK). Maturę uzyskał dopiero w 1957 r. w trybie eksternistycznym. 26 grudnia tego roku diakon Nowik przyjął bez przeszkód święcenia kapłańskie w Gorzowie Wielkopolskim ${ }^{71}$. Od 1958 r. na Katolickim Uniwersytecie Lubelskim kontynuował rozpoczęte wcześniej w warszawskiej ATK studia filozoficzne, które uwieńczył w 1961 r., broniąc pracę pt. „Zagadnienie przyczynowości w przypadku mutacji genowej”72. Po okresie studiów w dziedzinie biologii na Uniwersytecie Marii Curie-Skłodowskiej (UMCS), równoczesnym realizowaniu zajęć dydaktycznych w Sekcji Filozofii Przyrody Ożywionej KUL na stanowisku starszego asystenta, w 1966 r. uzyskał stopień naukowy doktora filozofii na podstawie pracy zatytułowanej „Pojęcie przyczynowości w naukach biologicznych" ${ }^{\prime 73}$. W tym czasie ks. Nowik był już w pełni ukształtowaną intelektualnie i duchowo osobowością, zdolną do odpowiedzialnej realizacji dojrzałej misji duszpastersko-wychowawczej, naukowej, społeczno-politycznej i patriotycznej.

68 J.M. Grabińska, Myśl patriotyczna księdza profesora, s. 12.

69 Gdy około 1942 lub 1943 r. Henryk przyjął w sakramencie bierzmowania imię Andrzeja Boboli, tenże patron Kresów i Polski powiedział mu we śnie: „musisz być księdzem", tamże, s. 13.

70 Osobę ks. Józefa Ferensowicza wymienia Konrad Konkol w załączniku artykułu w tabeli 1; tenże, Organy bezpieczeństwa wobec Niższego Seminarium Duchownego w Stupsku, „Słupskie Studia Historyczne”, 20 (2014) s. 236.

71 J.M. Grabińska, Myśl patriotyczna księdza profesora, s. 13.

72 Tamże, s. 13.

73 Tamże, s. 13. 


\section{Misja duszpastersko-wychowawcza, naukowa, społeczno-polityczna i patriotyczna ks. Nowika}

Tragizm sytuacji, w jakiej znalazły się Kresy Wschodnie, w tym Wołyń, w czasie drugiej wojny światowej, wywarł niezatarty wpływ na osobowość i późniejszą działalnośc ${ }^{74}$ ks. Nowika. Joanna Maria Grabińska stwierdziła, iż charakter tej działalności upodabniał ją do działań ks. kardynała Stefana Wyszyńskiego. Tak jak Prymas Tysiąclecia, ks. Nowik wierny był przede wszystkim Chrystusowemu kapłaństwu, a praca naukowa, dydaktyczno-wychowawcza i połączona z nimi misja duszpastersko-wychowawcza stanowiły funkcjonalne dopełnienie prezbiteratu. Wyróżniała go nadzwyczajna aktywność i wielokierunkowość działania: praca duszpastersko-wychowawcza (w Szczecinie), naukowa (teologiczna, metodologiczna, interdyscyplinarna), dydaktyczno-wychowawcza w Wyższym Seminarium Duchownym (w Paradyżu), duszpastersko-parafialna i katechetyczna (w Zielonej Górze), funkcja proboszcza i działalność duszpastersko-parafialna w Czerwieńsku ${ }^{75}$ oraz społeczna w Zielonej Górze. Jako kapelan brał udział w protestach społeczno-robotniczych w fabryce „Zastal”, był doradcą zarządu regionu, kapelanem rolników oraz robotników zrzeszonych w Niezależnym Samorządnym Związku Zawodowym „Solidarność”. Edukował ich przez kazania z zakresu nauki społecznej Kościoła, historii Polski, historiozoficznego znaczenia wydarzeń narodowych. Uczył rozumnej wiary, patriotyzmu, odpowiedzialności za rozwiązywanie problemów kraju (np. gospodarczych) w duchu solidarności narodowej i chrześcijańskiej. Wskazywał na godziwe moralnie kierunki rozwoju społecznego, odpowiedzialność indywidualną i zbiorową za dziedzictwo kulturowe, uwrażliwiał sumienia. W 1981 r. odważnie współorganizował rozmowy z delegacją rządową w obronie pracowników i działaczy związkowych Niezależnego Samorządnego Związku Zawodowego Rolników Indywidualnych „Solidarność", a także zwalnianych z pracy w regionie lubuskim. Delegacja rządowa została tam przysłana na polecenie premiera Wojciecha Jaruzelskiego. Wobec impasu w rozmowach, w negocjacje zaangażował się Lech Wałęsa, uznając postulaty strajkowe ${ }^{76}$ za uzasadnione dzięki roztropnym sugestiom księdza.

74 J. Kolbuszewski, Kresy, Wrocław 2002; Kresy - pojęcie i rzeczywistość. Zbiór studiów, red. K. Handke, Warszawa 1997, s. 7-270.

75 J.M. Grabińska, Myśl patriotyczna księdza profesora, s. 13.

76 Tamże, s. 15. 
W dniu 3 maja 1981 r. przy zielonogórskim amfiteatrze ks. Nowik celebrował mszę św. za Ojczyznę, dla zgromadzonych tam robotników i działaczy związkowych Regionu Zielonogórskiego NSzZ „Solidarność”. Wygłaszając religijno-patriotyczne kazanie, zainicjował budowę pomnika zainspirowanego ofiarnością swej matki, jej trudnym kresowym życiem, dziejami Kościoła i Ojczyzny, który ostatecznie stanął na placu przed sanktuarium w Licheniu i został poświęcony 16 października 1987 r. Pomnik ten z inspiracji tzw. Przesłania Gnieźnieńskiego papieża Jana Pawła II z dnia 3 czerwca 1979 r. oraz z inicjatywy ks. Nowika otrzymał nazwę: „Pomnik Matki Ojczyzny w Hołdzie Matce Polce"77. Realizując powierzoną mu misję, 12 maja $1981 \mathrm{r}$. w warszawskiej katedrze św. Jana uczestniczył z bp. Władysławem Miziołkiem we mszy św. koncelebrowanej, sprawowanej z okazji zarejestrowania Nszz Rolników Indywidualnych „Solidarność". Jak podkreślano, Prymas Tysiąclecia „walczył o tę rejestrację i przyszło zwycięstwo" $^{\prime 78}$. W warunkach konspiracyjnych stanu wojennego ks. Nowik doprowadził do wykonania sztandaru NSZZ „Solidarność” Regionu Zielonogórskiego, złożonego w Sanktuarium w Rokitnie jako votum dziękczynne za ocalenie Ojczyzny.

Na szczególną uwagę zasługuje kontynuowana przez niego obrona życia dzieci nienarodzonych, zainicjowanie teatru jednego aktora przedstawiającego zagadnienia z problematyki nauki społecznej Kościoła, zaangażowanie w duszpasterstwo pątnicze rolników regionu zielonogórskiego na Jasną Górę (w 1981 r.), kontynuowanie kazań patriotycznych w latach osiemdziesiątych, założenie w 1981 r. zielonogórskiego Uniwersytetu Związków Zawodowych „Solidarność” im. kard. Stefana Wyszyńskiego. Uniwersytet miał kształtować ludzi pracy w duchu katolickiej nauki społecznej. W 1981 r. ks. Nowik brał udział w powołaniu „Tygodnika NSzz Ri Solidarność” w tzw. Domu Chłopa w Warszawie ${ }^{79} .13$ grudnia 1981 r. po ogłoszeniu stanu wojennego zainicjował powstanie Zespołu Charytatywnego z siedzibą główną w Czerwieńsku oraz filiami położonymi w wielu miejscowościach, z sekcją: żywnościową, medyczno-lekarską, farmaceutyczną, prawną. Po rozmowach Okrągłego Stołu utworzył w 1990 r. w Zielonej Górze Towarzystwo Kultury Narodowo-Religijnej, w celu zjednoczenia patriotów polskich wokół najistotniejszych spraw Ojczyzny. Jego członkowie wyrażali

77 Tamże, s. 14.

78 Tamże, s. 14.

79 Tamże, s. 14. 
zastrzeżenie, iż Polska nie powinna wstępować do Unii Europejskiej ze względu na bardzo niekorzystne warunki przyszłej akcesji. Negocjowaniem sprawiedliwszych warunków zająć się miało założone przez księdza Stowarzyszenie Ogólnonarodowego Porozumienia „Polska Bogiem Silna” przy asystencji ks. bp. Kazimierza Majdańskiego. Statut stowarzyszenia opracował ks. Nowik, jednakże nie zostało ono zarejestrowane. Jako alternatywę powołał instytucję o profetycznej nazwie: Towarzystwo Kultury Narodowo-Religijnej „Polska Bogiem Silna” im. Jana Pawła II ${ }^{80}$. Idee towarzystwa przedstawił w wielu publikacjach, wykładach i wystąpieniach publicznych, zjazdach społeczno-politycznych, naukowych, religijno-patriotycznych pielgrzymkach narodu polskiego, programach Radia

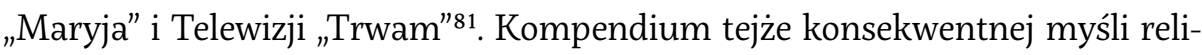
gijno-patriotycznej księdza zawarte zostało przede wszystkim w miesięczniku społeczno-kulturalnym „Nad Odrą" ${ }^{82}$, założonym przez niego w 1990 roku $^{83}$. Wydawane w Zielonej Górze nieustannie od 25 lat mobilizuje do utrzymania silnie zinternalizowanej tożsamości polskiej. Obowiązek ten legitymizują: poczucie misji, powołanie oraz posłannictwo dziejowe Polaków, odzyskanie i utrzymanie niepodległości narodu i państwa, wolność Kościoła rzymskokatolickiego, kultywowanie wartości narodowo-religijnych w tym chrześcijańskiego patriotyzmu, solidarności, historiozoficznej świadomości „blasków i cieni” narodu, odwoływanie się w tym zadaniu do nadprzyrodzonej mocy Boga, pomocy Matki Bożej, wstawiennictwa świętych Kościoła rzymskokatolickiego (m.in. św. Andrzeja Boboli, św. Jana Pawła II Wielkiego, bł. ks. Jerzego Popiełuszki), dawnych i współczesnych patriotów. Ks. Nowik wskazuje na konieczność zachowania prawości sumienia, pogłębionej duchowości, realizmu, patriotyzmu, historycznej ciągłości „narodowego ruchu religijnego, umacnianych wydarzeniami dziejowymi od Chrztu Polski (966) do wyboru Papieża Polaka ${ }^{84}$ (1978). Myśl swoją kieruje

8o Tamże, s. 18.

81 Tamże, s. 16.

82 W ramach miesięcznika „Nad Odrą” z inicjatywy Jana Nowika wydawane są cenne aneksy: „Eidos” (zał. przez ks. Nowika), „Nasz wybór” (zał. przez Jana Nowika), „Dziedzictwo Testamentowe Jana Pawła II” (zał. przez J. Nowika), „Informator dla poszkodowanych w wypadkach drogowych" (zał. przez J. Nowika); J. M. Grabińska, Myśl patriotyczna księdza profesora, s. 19.

83 Tamże, s. 17.

84 Tamże, s. 16. 
również do narodów Europy Środkowo-Wschodniej. To wszystko złożyło się na imperatyw założycielski miesięcznika "Nad Odrą", wzmacniający uzasadnioną historycznie polskość Kresów Zachodnich ${ }^{85}$.

W przekonaniu ks. Nowika chrześcijańska misja dziejowa Polski jeszcze się nie zakończyła. Bowiem wolność Kościoła i niepodległość Ojczyzny, którym całe życie służy, unitarność obszarów wschodnich i zachodnich obecnej RP, są dzisiaj szczególnie zagrożone. Toteż:

[...] miesięcznik ma integrować ludzi dobrej woli bez względu na ich narodowość. [...] dostrzegać inspirującą rolę religii w kulturze, [...] ukazywać piękno i bogactwo kultury narodowej i religijnej Polaków, Niemców, Żydów, Ukraińców, Białorusinów, Litwinów ${ }^{86}$, Rosjan, Czechów, Słowaków itd. [...] Elementami jednoczącymi winna być działalność kulturalna i naukowa, [...] stwarzająca możliwość wymiany poglądów, idei i programów pomiędzy środowiskami ludzi kultury, nauki, polityki w poszczególnych regionach oraz w skali kraju i poza granicami Polski ${ }^{87}$.

Dla realizacji tychże idei na stronicach „Miesięcznika” opublikowano autorskie opracowania niemal 200 wybitnych intelektualistów: duchownych i świeckich (dane z 2013 r.) ${ }^{88}$. Na problematykę około 2000 publikacji składały się m.in. zagadnienia kulturowe: z przeszłości Polski i Kościoła rzymskokatolickiego, chrześcijańskiej otwartości i gościnności Polaków skierowanej ku innym grupom etnicznym. Poruszano zagadnienia cywilizacyjne, kulturowo-antropologiczne, filozoficzne (m.in. personalizm), chrystocentryczne, stwórcze, eschatologiczne, sensu dziejów, dotyczące nauczania Stolicy Apostolskiej (nauki społecznej Kościoła, nauczania Jana Pawła II), międzynarodowe, państwowotwórcze, politologiczne, polityczne, krytyczno-ustrojowe, polemologiczne (problematyka wojny i walki), totalitaryzmu ${ }^{89}$ i jego form, zła duchowo-osobowego

85 T. Nodzyński, „Strażnica Zachodnia” 1922-1939. Źródło do dziejów myśli zachodniej w Polsce, Zielona Góra 1997, s. 83.

86 K. Podlaski (Bohdan Skaradziński), Białorusini, Litwini, Ukraińcy, Białystok 199o, s. 18. 87 M. Grabińska, Myśl patriotyczna księdza profesora, s. 17.

88 Należą do nich m.in.: arcybiskupi Stanisław Wielgus, Kazimierz Majdański, Andrzej Dzięga, Stanisław Gądecki, Sławoj Leszek Głódź, Mieczysław Mokrzycki i biskupi: Wiesław Mering, Ignacy Dec; tamże, s. 18.

89 M. Kornat, Bolszewizm, s. 53-56. 
i moralnego (zorganizowanego strukturalnie), także o charakterze antypedagogicznym. Bardzo ważnym obszarem przedstawionych w „Miesięczniku” badań jest zagadnienie „wychowania do pokoju" ${ }^{\prime \prime 0}$, obrony praw człowieka, godności osoby ludzkiej, prawa do życia od poczęcia do naturalnej śmierci, zachowania życia w skali globalnej. W duchu najwyższej odpowiedzialności obywatelskiej za losy narodu, państwa, Kościoła i Ojczyzny przy akceptacji ks. Nowika, redaktor aneksu „Nasz Wybór”, Jan Nowik, zredagował projekt Ustawy Zasadniczej państwa polskiego, której preambułę przedstawił na stronach tegoż miesięcz-

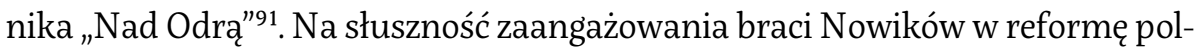
skiego konstytucjonalizmu wskazują rozpoczęte konsultacje społeczne w sprawie nowelizacji przyszłej Konstytucji RP w 2017 r.

\section{Konsekwencje kresowości dla duszpastersko-wychowawczego wymiaru misji ks. Nowika}

Podsumowując eksplanowane w artykule dokonania ks. Nowika, wspaniałego człowieka i duszpasterza-pedagoga, należało skonfrontować je ze stanem świadomości tych, którzy

[...] znając Księdza Profesora wiedzieli, że jest to charyzmatyczny, niezwykły Kapłan, ale niewielu zdawało sobie sprawę z tego, że całe jego życie to wielka historia należąca do wątków chlubnej i tragicznej historii narodu polskiego. Nie sposób w krótkim tekście ująć wszystkie aspekty jego działalności ${ }^{92}$.

Przeprowadzone badania biograficzne upoważniają do wyrażenia przekonania, iż ten kresowy duszpasterz, teolog, społecznik, pedagog i intelektualista wykonał niezmiernie trudną do ogarnięcia, olbrzymią pracę duszpastersko-wychowawczą w różnych jej kontekstach, wielokrotnie śmielszą ponad zwykłą miarę ludzką. Jako kapłan o nastawieniu mistycznym i patriota, „arystokrata ducha”,

90 R. Małachowski, Kroskulturowe aspekty wojny i walki w globalnej przestrzeni wychowania. Perspektywa historiozoficzna, w: Edukacyjne przestrzenie, Wybrane problemy pedeutologii, opieki i wychowania $w$ ujęciu komplementarnym, red. R. Fudali, Zielona Góra 2010, s. 11-62.

91 M. Grabińska, Myśl patriotyczna księdza profesora, s. 20.

92 Tamże, s. 11. 
wrażliwy moralnie człowiek, „mistrz” i uczony odznacza się nieczęsto spotykaną kulturą intelektualną i moralną. Również w opinii społeczności Dolnego Śląska jest heroiczną osobowością, obrońcą historycznego etosu Kresów Wschodnich i Zachodnich, kontynuatorem i współtwórcą polskiej kultury narodowej ${ }^{93}$. Mówi się i pisze, że: „swoją postawą wyrażoną w działaniu na rzecz wolnej Polski był i jest - wzorem kapłana oddanego bez reszty ludziom i Ojczyźnie" ${ }^{\prime \prime}$, podobnym do „śp. kardynała Stefana Wyszyńskiego" ${ }^{95}$. W związku z ofensywą „dyktatury relatywizmu"96 w XX i XXI w., świadomy odpowiedzialności przed Bogiem, zaangażował do działalności kulturowej i kulturotwórczej: duszpasterskiej, religijno-patriotycznej, naukowej, wydawniczej, społecznej, społeczno-politycznej, związkowej, charytatywnej, setki oddanych „Ojczyźnie i Kościołowi Polaków, w tym świecką i duchowną młodzież akademicką. Dojrzałość moralno-etyczna, wielka skromność bycia, heroiczne zawierzenie Bogu, samowychowanie, odwaga, męstwo, wytrwałość, „osoba i czyn”, „miłość i odpowiedzialność” (wpływ papieża św. Jana Pawła II ${ }^{97}$ ), to czynniki, które dopełniły biograficzny wizerunek księdza.

Fundamentalnym imperatywem tego stanu rzeczy było i jest - jak sam wspominał - przede wszystkim wychowawczo-kulturowe oddziaływanie rodzinnego domu oraz innych przestrzeni i środowisk Kresów Wschodnich II RP. W tym znaczeniu we współczesnej Polsce wiele biografiii ${ }^{98}$, także biografia ks. Nowika i podobnych mu duszpasterzy - wychowawców wraz z kulturowym dorobkiem Kresów, winna stać się fundamentalną częścią programów edukacyjno-wychowawczych (katechezy, lekcji języka polskiego, historii, geografii,

93 Założyciel i wydawca miesięcznika: „Nad Odrą” (1991), wydawanego przez Towarzystwo Kultury Narodowo-Religijnej „Polska Bogiem Silna” im. Jana Pawła II (założonego przez tegoż ks. dr. H. Nowika w 1991 r.).

94 J.M. Grabińska, Myśl patriotyczna księdza profesora, s. 13.

95 Tamże, s. 13.

96 Papież Benedykt XVI: „mówił wprost o dyktaturze relatywizmu, która «w gruncie rzeczy jest zagrożeniem dla ludzkiej wolności»". Papież Franciszek naucza, iż: dyktatura relatywizmu „czyni każdego miarą samego siebie”; Z. Grocholewski, Relatywizm niszczy formację akademicka, , Nasz Dziennik", 96 (2015) s. 26.

97 K. Wojtyła, Miłość i odpowiedzialność, Człowiek i moralność, cz. 1, red. T. Styczeń, J.W. Gałkowski, A. Rodziński, A. Szostek, Lublin 1986.

98 Patrz: biografia autorstwa Józefa Szczypka, w: tenże, Jan Paweł II. Rodowód, Warszawa 1989; D. Gronowski, Bp Wilhelm Pluta. Biografia, Gorzów Wielkopolski-Zielona Góra 2015. 
zajęć fakultatywnych z muzyki i plastyki, wycieczek szkolnych). Ponieważ w PRL ciągłość kresowej tradycji kulturowej i tematyka Kresów Wschodnich została arbitralnie przerwana i usunięta ze wszystkich stopni nauczania oraz wychowania, również po 1989 r. (nazwę PRL zamieniono na „Rzeczpospolita Polska" uchwałą sejmu 29 grudnia 1989 r.) nie wróciła do polskiego systemu oświatowego, inicjatywa ta jest nadal aktualna. Wymaga tego wierność polskiej racji stanu, zobowiązująca do ustawicznej internalizacji treści, wartości, zadań i obowiązków wynikających z przyjęcia cywilizacji chrześcijańskiej, jako podstawy kulturowej Polaków oraz prawo do utrwalania tożsamości narodowej. Realizacją tegoż programu winni zająć się nauczyciele świeckich i katolickich szkół podstawowych, średnich i wyższych (m.in. wykłady z: literatury ${ }^{99}$, poezji, muzyki, malarstwa - Kresów Wschodnich, historii wychowania, pedagogiki kultury), seminariów duchownych w Polsce i poza jej granicami. W moim przekonaniu artykuł ten, a przede wszystkim biografia pedagogiczna, misja i myśl naukowa ${ }^{100}$, oraz religijno-patriotyczny czyn duszpastersko-wychowawczy ks. Nowika, wraz z innymi biografiami kresowymi może stanowić odpowiedni do tego przyczynek.

Streszczenie: Artykuł dotyczy ks. dr. Henryka Nowika urodzonego w 1933 r., w polskiej rodzinie religijnej i patriotycznej. Najpierw ministrant, w 1951 r. przyjęty do Wyższego Seminarium Duchownego w Gorzowie Wielkopolskim, w 1957 r. przyjął święcenia kapłańskie. W 1958 r. podjął studia filozoficzne na Katolickim Uniwersytecie Lubelskim. W 1966 r. uzyskał stopień naukowy doktora filozofii. Pełniąc funkcję proboszcza, prowadził działalność społeczno-patriotyczną. Na gruncie duszpastersko-wychowawczym:

99 „Ogromnie zasłużony dla wychowania studentów znawca problematyki kresowej II Rzeczypospolitej Bolesław Hadaczek wskazuje na w zupełności oryginalną pedagogiczno-wychowawczą rolę literatury, poezji i przyrody kresowej w okresie międzywojennym"; R. Małachowski, Działalność wychowawcza księdza Aleksandra Zienkiewicza na Kresach Wschodnich Rzeczypospolitej i Dolnym Ślasku, wyd. 1, Zielona Góra 2013, s. 427. B. Hadaczek uczynił literaturę i poezję Kresów Wschodnich II RP przedmiotem wykładowym na Uniwersytecie Szczecińskim.

100 Ks. dr Nowik wydał drukiem 339 publikacji naukowych dotyczących istotnych poznawczo zagadnień. W przygotowaniu znajdują się dwie kolejne publikacje książkowe: Empiriologiczna fenomenologia biosystemów oraz Koncepcja przyczynowości $w$ biologii i filozofii, informacja uzyskana od ks. dr. H. Nowika. Joanna Maria Grabińska pisze o 315 publikacjach [zamiast 339]; J. M. Grabińska, Myśl patriotyczna księdza profesora, s. 20-27. 
kapłańskim, społeczno-politycznym, jako kapelan, brał udział w protestach robotników polskich, był doradcą i kapelanem chłopów, inspirował obronę życia poczętego, duszpasterstwo pątnicze rolników.

Ks. Nowik, „arystokrata ducha”, wrażliwy moralnie człowiek, uczony (teolog, biolog, filozof, pedagog), asceta, człowiek ducha modlitwy. Ukryta osobowość mistyczna, odznaczająca się nieczęsto spotykaną kulturą intelektualną i moralną. Zaangażowany w prace na rzecz „Ojczyzny”, Kościoła katolickiego, człowieka i społeczeństwa. Mimo ofensywy dyktatury relatywizmu w XX i XXI w. zaangażował do działalności kulturotwórczej setki oddanych Ojczyźnie i Kościołowi Polaków, w tym młodzież akademicką". Dlatego w opinii społeczności Dolnego Śląska jest wzorem kapłana, podobnym do śp. Kardynała Stefana Wyszyńskiego, wielką osobowością, spowiednikiem i duszpasterzem-wychowawcą, krzewicielem historycznego ethosu Kresów Wschodnich i Zachodnich, patriotą, kontynuatorem i współtwórcą polskiej kultury narodowej, a przy tym wybitnym społecznikiem, godnym naśladowania przez ludzi świeckich i duchownych.

Słowa klucze: kresowa biografia pedagogiczna, duszpastersko-wychowawcza misja, kapłan, społecznik, patriota

\section{Bibliografia}

Białek J. Z., Literatura dla dzieci i młodzieży w latach 1918-1939, Zarys monograficzny, Materiały, Warszawa 1979.

Bonusiak W., Polska podczas II wojny światowej, Rzeszów 1995.

Dziedzictwo Kresów - nasze wspólne dziedzictwo?, red. J. Purchla, Kraków 2006.

Edukacyjne przestrzenie. Wybrane problemy pedeutologii, opieki i wychowania w ujęciu komplementarnym, red. R. Fudali, Zielona Góra 2010.

Encyklopedia Kresów, red. M. Karolczuk-Kędzierska, Kraków [b.r.].

Europa nieprowincjonalna: przemiany na ziemiach wschodnich dawnej Rzeczypospolitej (Białoruś, Litwa, Łotwa, Ukraina, wschodnie pogranicze III Rzeczypospolitej Polskiej) w latach 1772-1999, red. K. Jasiewicz, Warszawa 1999.

Fijałka M., 27. Wołyńska Dywizja Piechoty AK, Warszawa 1986.

Fijałkowski W., Urodzić się w domu, w: Oblicza dzieciństwa, red. D. Kornas-Biela, Lublin 2001. Filar W., Wołyń 1939-1944. Eksterminacja czy walki polsko-ukrainskie. Studium historyczno-wojskowe zmagań na Wołyniu w obronie polskości, wiary i godności ludzkiej, Toruń 2003.

Filar W., Wołyń 1939-1944. Historia, pamięć, pojednanie, Warszawa 2009.

Gałka B. W., Ziemianie i ich organizacje w Polsce lat 1918-1939, Toruń 1997.

Głębocki H., Kresy imperium, Szkice i materiały do dziejów polityki Rosji wobec jej peryferii (XVIII-XXI wiek), Kraków 2006. 
Grabińska J. M., Myśl patriotyczna księdza profesora doktora Henryka Nowika - charyzmatycznego Kapłana oddanego Kościołowi i Ojczyźnie, „Nad Odrą”, (2013) nr 9-12.

Grocholewski Z., Relatywizm niszczy formację akademicka, „Nasz Dziennik”, (2015) nr 96.

Gronowski D., Bp Wilhelm Pluta. Biografia, Gorzów Wielkopolski-Zielona Góra 2015.

Grünberg K., Adolf Hitler, Biografia Fürera, Warszawa 1988.

Hadaczek B., Historia literatury kresowej, Szczecin 2008.

Hadaczek B., Wychowanie przez literaturę w Polsce międzywojennej (związki literatury dla dzieci i młodzieży z pedagogika), Rozprawy i Studia, t. 4, Warszawa-Poznań 1973.

Kalbarczyk S., Polscy pracownicy nauki, Ofiary zbrodni sowieckich $w$ latach II wojny światowej. Zamordowani, więzieni, deportowani, Warszawa 2001.

Kaniowska-Lewańska I., Literatura dla dzieci i młodzieży do roku 1864: zarys rozwoju. Wybór materiałów, Warszawa 1973.

Kapralska Ł., Pluralizm kulturowy i etniczny a odrębność regionalna Kresów południowo-wschodnich w latach 1918-1939, Kraków 2002.

Karłowicz L., Od Zasmyk do Skrobowa, Opole 1994.

Kaszuba E., System propagandy państwowej obozu rządzącego w Polsce w latach 19261939, Toruń 2004

Konkol K., Organy bezpieczeństwa wobec Niższego Seminarium Duchownego w Stupsku, „Słupskie Studia Historyczne”, 2014, nr 20.

Korman A., Stosunek UPA do Polaków na ziemiach południowo-wschodnich II Rzeczypospolitej, Wrocław 2002.

Kornat M., Bolszewizm, totalitaryzm, rewolucja. Rosja. Początki sowietologii i studiów nad systemami totalitarnymi w Polsce (1918-1939), cz. 4, Kraków 2003.

Kowalczyk S., Z refleksji nad człowiekiem. Człowiek-społeczność-wartość, Lublin 1995. Krasowski L. „Lech”, Wołyński oddział „Kozaka”, Szczecin 1996.

Kresy - pojęcie i rzeczywistość, Zbiór studiów, red. K. Handke, Warszawa 1997.

Lewandowska S., Życie codzienne Wilna w latach II wojny światowej, Warszawa 2001.

Lewkowska A., Lewkowski J., Zabytkowe cmentarze na Kresach Wschodnich Drugiej Rzeczypospolitej, Województwo wileńskie na obszarze Republiki Białorusi, Warszawa 2007.

Lipiński W., Walka zbrojna o niepodległość Polski 1905-1918, wyd. 2, rozszerzone, Warszawa 1935.

Lista strat kultury polskiej (1.IX.1939 - 1.III.1946), zestawił: B. Olszewicz, Warszawa 1947.

Małachowski R. , Działalność wychowawcza księdza Aleksandra Zienkiewicza na Kresach Wschodnich Rzeczypospolitej i Dolnym Śląsu, Zielona Góra 2013.

Małachowski R., Kroskulturowe aspekty wojny i walki w globalnej przestrzeni wychowania. Perspektywa historiozoficzna, w: Edukacyjne przestrzenie, Wybrane problemy pedeutologii, opieki i wychowania w ujęciu komplementarnym, red. R. Fudali, Zielona Góra 2010, s. 11-62. 
Mierzwiński B., Ojcostwo Boże źródłem i wzorem ojcostwa ziemskiego, w: Oblicze Ojcostwa, red. D. Kornas-Biela, Lublin 2001.

Nawroczyński B., Polska myśl pedagogiczna. Jej główne linie rozwojowe. Stan współczesny i cechy charakterystyczne, Lwów-Warszawa 1938.

Nieciuński W., Przemoc i masowe zbrodnie hitleryzmu i stalinizmu. Próba studium porównawczego, Warszawa 1998.

Nodzyński T., „Strażnica Zachodnia” 1922-1939. Źródło do dziejów myśli zachodniej w Polsce, Zielona Góra 1997.

Nowik H., Autobiograficzne wspomnienia rodzinne księdza Henryka Nowika, Kresy Południowo-Wschodnie (1918-2016), Zielona Góra 2016, mps w zbiorach autora.

Oblicze ojcostwa, red. D. Kornas-Biela, Lublin 2001.

O dialogu kultur wspólnot kresowych, red. S. Uliasz, Rzeszów 1998.

Okoń Z., Kresowi sąsiedzi. W szponach trzech ludobójczych hord, Rzeszów 2005.

Okupacja sowiecka ziem polskich 1939-1941, red. P. Chmielowiec, Rzeszów-Warszawa 2005.

Parzyszek M., Rodzina w nauczaniu kardynała Stefana Wyszyńskiego. Aspekt pedagogiczny, Lublin 2012.

Piotrowski Cz., Wojskowe i historyczne tradycje 27. Wołyńskiej dywizji Piechoty Armii Krajowej, Warszawa 1993.

Podlaski K. (Bohdan Skaradziński), Białorusini, Litwini, Ukraińcy, Białystok 1990.

Poliszczuk W., Dowody zbrodni ouN i UPA, Integralny nacjonalizm ukraiński jako odmiana faszyzmu, t. 2: Działalność ukrainskich struktur nacjonalistycznych w latach 1920-1999, Toronto 2000.

Poliszczuk W., Fałszowanie historii najnowszej Ukrainy. Wołyń - 1943 i jego znaczenie, Toronto-Warszawa 1996.

Poliszczuk W., Rok 1943: oun Bandery na Wołyniu. Działalność oun Bandery w świetle „Listów otwartych do Przywództwa oun Bandery" autorstwa Tarasa Bulby-Borowca, Przyczynek do oceny politycznej i prawnej oun Bandery, Dokumenty z pracy, Warszawa 2002.

Polit I., Miejsce odosobnienia w Berezie Kartuskiej w latach 1934-1939, Toruń 2003.

Prus E., UPA armia powstańcza czy kurenie rizunów?, Wrocław 1994.

Pruszak T. A., O ziemiańskim świętowaniu. Tradycje świąt Bożego Narodzenia i Wielkiejnocy, Warszawa 2011.

Przed akcja „Wisła” był Wołyń, red. W. Filar, Warszawa 1997.

Przemiany narodowościowe na Kresach Wschodnich II Rzeczypospolitej 1931-1948, red.

S. Ciesielski, Toruń 2003.

Przesiedlenie ludności polskiej z Kresów Wschodnich do Polski 1944-1947, wyb., oprac. i red. S. Ciesielski, Warszawa 1999.

Przybysz A., Wspomnienie z umęczonego Wołynia, Wrocław 2000.

Rokuszewska-Pawełek A., Chaos i przymus. Trajektorie wojenne Polaków - analiza biograficzna, Łódź 2002. 
Romanowski W., Kainowe dni, Warszawa 1990.

Siemaszko W., Siemaszko E., Ludobójstwo dokonane przez nacjonalistów ukraińskich na ludności polskiej Wołynia 1939-1945, t. 1-2, Warszawa 2000.

Stobniak-Smogorzewska J., Kresowe osadnictwo wojskowe 1920-1945, Warszawa 2003.

Stryjek T., Jakiej przeszłości potrzebuje przyszłość? Interpretacje dziejów narodowych w historiografii i debacie publicznej na Ukrainie 1991-2004, Warszawa 2007.

Szczypka J., Jan Paweł II. Rodowód, Warszawa 1989.

Tomkiewicz M., Zbrodnia w Ponarach 1941-1944, Warszawa 2008.

Węglicka K., Kresowym szlakiem, Gawędy o miejscach, ludziach i zdarzeniach, Warszawa 2006.

Węgorowska K., Językowe świadectwa kultury i obyczajowości Kresów Północno-Wschodnich, Utrwalone we wspomnieniach ich byłych mieszkańców, Zielona Góra 2004.

Wojtyła K., Miłość i odpowiedzialność. Człowiek i moralność, cz. 1, red. T. Styczeń, J.W. Gałkowski, A. Rodziński, A. Szostek, Lublin 1986.

Zasztoft L., Kresy 1832-1864, Szkolnictwo na ziemiach litewskich i ruskich dawnej Rzeczypospolitej, Warszawa 1997.

Zawilski A., Znów ożywają kurhany, Wrocław 1997.

Z zagadnień kultury chrześcijańskiej, red. K. Wojtyła i in., Lublin 1973.

Ziemnowicz M., Rodzina a wychowanie państwowe, Lwów-Warszawa 1933.

Żupański A., Droga do prawdy o wydarzeniach na Wołyniu, Toruń 2006. 